\title{
PHYSIOLOGICAL CHANGES DURING POSTHARVEST SENESCENCE OF BROCCOLI ${ }^{1}$
}

\author{
FERNANDO LUIZ FINGER ${ }^{2}$, LAURÍCIO ENDRES ${ }^{3}$, PAULO ROBERTO MOSQUIM ${ }^{4}$ and MÁRIO PUIATTI ${ }^{5}$
}

\begin{abstract}
The objective of this work was to determine the early physiological changes throughout shelf life of fresh broccoli (Brassica oleracea L. var. italica) cv. Piracicaba Precoce at $25^{\circ} \mathrm{C}$ and relative humidity of $96 \%$ in the dark until complete senescence. Head inflorescences showed lack of turgidity and commercial value when weight loss reached up to $5 \%$, coinciding with 48 hour after harvest. Chlorophyll content was stable until 24 hours after harvesting; afterwards, an intense degradation phase took place. At 72 hours, total head yellowing was observed when chlorophyll content dropped to $30 \%$ of its initial content. Peroxidase activity increased by 1.4 fold during the first six hours, dropping to its lowest level approximately 24 hours after harvesting. However, from this time on, an increment of activity was observed until 72 hours. At 24 hours after harvesting, respiration was reduced by $50 \%$. At later stages of senescence, respiration of florets was stable, but in a lower level than that determined at harvest. Sharp reduction of starch and reducing sugars was observed within 24 hours after harvesting, followed by continuous period of decline in starch and non-reducing sugars.
\end{abstract}

Index terms: chlorophyll, peroxidase, respiration, starch, soluble sugars.

\section{ALTERAÇÕES FISIOLÓGICAS DA SENESCÊNCIA PÓS-COLHEITA DE BRÓCOLIS}

\begin{abstract}
RESUMO - Alterações fisiológicas ocorridas durante a vida de prateleira em inflorescências de brócolis (Brassica oleracea L. var. italica) cv. Piracicaba Precoce foram avaliadas durante armazenamento a $25^{\circ} \mathrm{C}$ e umidade relativa de $96 \%$. A perda de turgidez e de valor comercial das inflorescências ocorreu 48 horas após a colheita, totalizando $5 \%$ de perda da matéria fresca. O conteúdo de clorofila permaneceu inalterado até 24 horas após a colheita, seguindo-se um período de intensa degradação. As inflorescências estavam completamente amarelas 72 horas após a colheita, quando apresentavam $30 \%$ do teor inicial de clorofila. A atividade peroxidativa elevou-se em 1,4 vezes nas seis horas subseqüentes à colheita, diminuindo até 24 horas, seguido de aumento da atividade até 72 horas pós-colheita. A respiração foi reduzida em 50\% nas primeiras 24 horas após a colheita, e permaneceu estável nos estádios finais do amarelecimento, mas com taxas inferiores às observadas na colheita. Os teores de amido e açúcares redutores sofreram quedas acentuadas nas 24 horas subseqüentes à colheita, bem como uma fase de persistente declínio do amido e de açúcares não-redutores.
\end{abstract}

Termos para indexação: clorofila, peroxidase, respiração, amido, açúcares solúveis.

\section{INTRODUCTION}

Fresh broccoli deteriorates quickly once harvested, mainly due to relatively high respiration

\footnotetext{
${ }^{1}$ Accepted for publication on November 16, 1998.

2 Agronomist, Ph.D., Dep. de Fitotecnia, UFV, CEP 36571-000 Viçosa, MG. E-mail: ffinger@mail.ufv.br

3 Agronomist, M.Sc., Dep. de Botânica, USP, CEP 05422-970 São Paulo, SP.

${ }^{4}$ Biologist, Dr., Dep. de Biologia Vegetal, UFV.

${ }^{5}$ Agronomist, Dr., Dep. de Fitotecnia, UFV.
}

and susceptibility to wilting when stored at room temperature (Gillies \& Toivonen, 1995). Since freshly harvested broccoli is composed by immature tissues, the inflorescence head shows rapid senescence and chlorophyll degradation (Clarke et al., 1994; Corcuff et al., 1996). Wang (1977) studied the length of broccoli shelf life and observed that after two or three days at $20^{\circ} \mathrm{C}$ the florets showed intense yellowing caused by sepal chlorophyll degradation. In addition, during the early hours after harvest, broccoli branchlets stored at $20^{\circ} \mathrm{C}$ showed sharp reduction of glucose and fructose 
contents (King \& Morris, 1994). This might be related to the high respiration rate observed in this vegetable (Kader, 1987; King \& Morris, 1994; Tian et al., 1995).

In Brazil several harvested fresh vegetables, such as broccoli, cauliflower and cabbage are not subjected to pre-cooling or refrigeration until they reach the consumer, which usually takes on average from one to three days. During this period, significant composition alterations might occur, affecting their quality and nutritional value.

The aim of this work was to investigate some physiological changes in the early shelf life of broccoli stored in the dark at room temperature $\left(25^{\circ} \mathrm{C}\right)$ and high relative humidity (96\%).

\section{MATERIAL AND METHODS}

Inflorescences of broccoli (Brassica oleracea L. var. italica) cv. Piracicaba Precoce were harvested when the heads were completely developed and without opened florets. The harvest of the inflorescences was carried out between 7 and 8 a.m. and immediately transported to the laboratory for desinfection in $1 \%$ sodium hypochloride solution for 15 minutes, followed by repeated washing with distilled water. Then, the heads were kept chambers under air flow of 60 liter hour ${ }^{-1}$ at $25^{\circ} \mathrm{C}$ and relative humidity of $96 \%$ until complete senescence. The storage was done under dark conditions, in order to avoid any interference of photosynthesis on chlorophyll breakdown and $\mathrm{CO}_{2}$ evolution.

The heads were weighed at harvest, 6, 12, 24, 48 and 72 hours after harvesting, and the losses of weight were expressed as percentage of fresh weight at harvest. The chlorophyll content of florets was evaluated according to Arnon (1949) and expressed as percentage of the harvest content.

Peroxidase activity in the florets was determined according to Lagrimini \& Rothstein (1987).

For respiration determination, samples of florets with approximately $15 \mathrm{~g}$ of fresh weight were obtained from the heads and the $\mathrm{CO}_{2}$ production evaluated with an IRGA equipped with a 1.5 liter chamber and a flow rate of 36 liter hour ${ }^{-1}$ at $20^{\circ} \mathrm{C}$ in the dark.

For soluble sugar analysis, $2 \mathrm{~g}$ of florets were extracted three times with boiling $80 \%$ ethanol. The ethanolic fraction was used for soluble and reducing sugars determinations (Hodge \& Hofreiter, 1962). The pellet resulting from the ethanol extraction was treated with $30 \%$ perchloric acid for starch determination (McCready et al.,
1950). For dry weight determinations, samples of florets were oven dry at $70^{\circ} \mathrm{C}$. All measurements were carried out in four replicates, composed by one head per replicate. Data from carbohydrates changes during storage were submitted to analysis of variance (ANOVA).

\section{RESULTS AND DISCUSSION}

The rate of fresh weight loss of the inflorescence head was somewhat constant throughout shelf life (Fig. 1A), this behavior shows that, in broccoli, like many other vegetables, the rate water loss is mainly dependent of temperature and humidity of the storage room (Finger \& Vieira, 1997). This constant rate on weight loss was also observed in broccoli stored at $13{ }^{\circ} \mathrm{C}$ and $95 \%$ relative humidity, in wrapped or unwrapped heads with micro-perforated film (Toivonen, 1997). The loss of inflorescence turgidity, evaluated by the presence of wilting, occurred when the dehydration reached up to $5 \%$, coinciding with 48 hours after harvest.

There was no significant chlorophyll degradation up to 24 hours after harvesting. However, an intense degreening in the florets took place after this period. At 72 hours of shelf life, the chlorophyll accounted for only $30 \%$ of its initial content (Fig. 1B) and complete yellowing of the inflorescence florets was observed. Clarke et al. (1994) also observed similar trend of chlorophyll degradation in florets during shelf life of broccoli cv. Shogun.

Specific activity of peroxidase had 1.4 fold increment over the first six hours after harvest, decreasing to its lowest level at 24 hours (Fig. 2). The initial increment in broccoli peroxidase activity seems to be caused by the stress of harvest. Simon \& Ross (1970) observed an increase of peroxidase activity following the injury of tobacco plants, which was spread out systemically throughout non damaged tissues. The intense drop in peroxidase activity after six hours from harvest, might reflect the end of the harvest stress effects.

The period following the first 24 after harvest was characterized by continuous increment of the peroxidase activity (Fig. 2), this may indicate the initial loss of membrane integrity (Thomas \& Stoddart, 1980). It has been proposed that several degrading reactions occur during organelles destruc- 
tion, including the synthesis of hydrogen peroxide (Elstner, 1982). Moreover, the presence of hydrogen peroxide increases the degreening in the flavedo tissues of satsuma mandarin fruits by peroxidase chlorophyll degrading pathway (Yamauchi et al., 1997). Therefore, in broccoli, the increase in peroxidase activity might represent a mechanism to eliminate hydrogen peroxide produced during later stages of degreening.

The results presented here show that weight loss, chlorophyll degradation and peroxidase activity seemed to be good indicators of broccoli senescence.

Florets respiration rate dropped by $50 \%$ in the first 24 hours after harvest, followed by slight
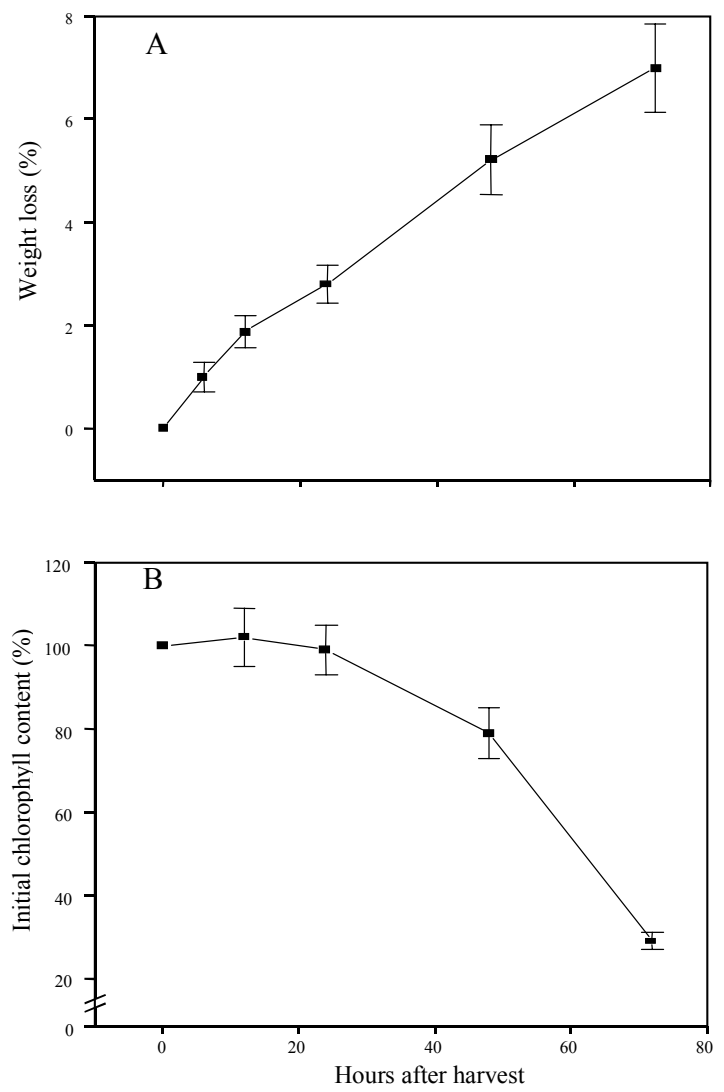

FIG. 1. Weight loss (A) and changes in chlorophyll content (B) of broccoli inflorescences throughout storage at $25^{\circ} \mathrm{C}$ and $96 \%$ relative humidity in the dark. Bars represent standard error. increase at later stages of shelf life (Fig. 3). The behavior of respiration observed here was similar to that observed by King \& Morris (1994) working broccoli cv. Green Belt stored at $20^{\circ} \mathrm{C}$. On the other hand, Tian et al. (1995) observed an increase of respiration up to 24 hours after harvesting for $\mathrm{cv}$. Shogun, and this was inversely proportional to floret size. Afterwards, the respiration declined up to 48 hours after harvesting, followed by a period of slight increase or stabilization, depending on the floret size. However, Irving \& Baird (1996) observed marked increments in the respiration of floret for the same cultivar stored at $20^{\circ} \mathrm{C}$ between 24 and 96 hours after harvesting. Therefore, it seems possible that the postharvest changes of respiration, in broccoli, might be cultivar dependent.

High contents of carbohydrates in detached organs are related to longer postharvest shelf life periods in vegetables like lettuce, cabbage and kale (Lipton, 1987; Amarante \& Puschmann, 1993). Here, starch content degraded immediately after harvest, showing total loss (significant at $\mathrm{P} \leq 0.05$ ) of $67 \%$ after 72 hours of storage (Fig. 4). A similar result was reported for broccoli cv. Shogun, where starch con-

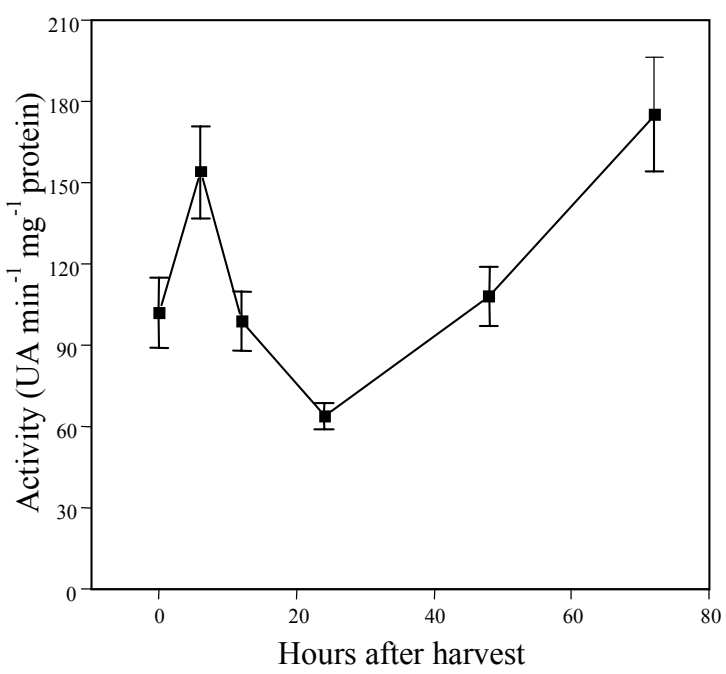

FIG. 2. Peroxidase specific activity during storage of broccoli inflorescences in the dark at $25^{\circ} \mathrm{C}$ and $96 \%$ relative humidity. Bars represent standard error.

Pesq. agropec. bras., Brasília, v.34, n.9, p.1565-1569, set. 1999 
tent decreased by $86 \%$ after 24 hours of storage at $20^{\circ} \mathrm{C}$ (Tian et al., 1997).

Associated with the starch drop, there was an increase of $31 \%$ in non-reducing sugars concentration

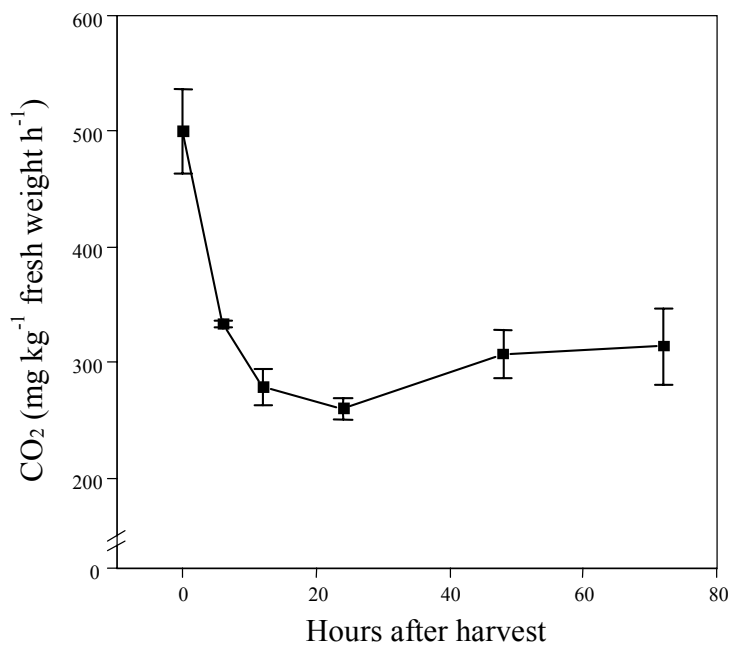

FIG.3. Respiration of broccoli florets during storage in the dark at $25^{\circ} \mathrm{C}$ and $96 \%$ relative humidity. Bars represent standard error.

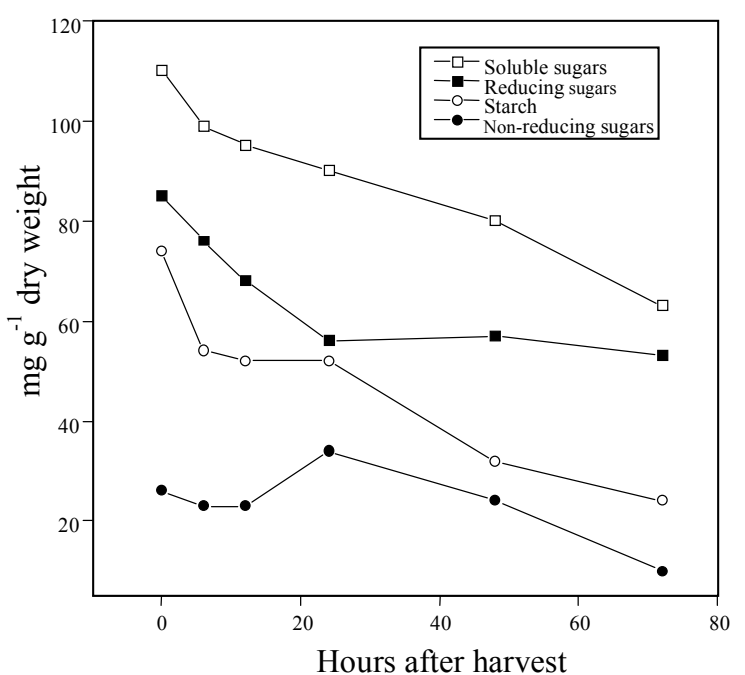

FIG. 4. Changes in starch, non-reducing sugars, total soluble sugars and reducing sugars content in broccoli florets stored in the dark at $25^{\circ} \mathrm{C}$ and $96 \%$ relative humidity. (significant at $\mathrm{P} \leq 0.05$ ) at 24 hours after harvesting (Fig. 4). This clearly shows that starch breakdown keeps the pool of soluble sugars in the florets. Towards the end of storage life, the non-reducing sugars showed persistent drop, and at 72 hours, the florets had consumed $71 \%$ its content at 24 hours after harvesting (significant at $\mathrm{P} \leq 0.05$ ) (Fig. 4). However, it has been reported by Downs et al. (1997) that sucrose content in broccoli cv. Shogun declined by $50 \%$ during the first six hours after harvesting.

As starch and reducing sugars contents are quickly reduced within 24 hours after harvesting, the decrease of reducing sugars seems to be associated with the losses of total soluble sugars (Fig. 4). The relationship between the changes of starch and soluble sugars showed that starch and reducing sugars are the main source of respiratory substrate during the initial postharvest life of broccoli, while at later stages, starch and non-reducing sugars have been more intensely metabolized. Our results showed that the short shelf life of broccoli is related to a marked depletion of carbohydrates, probably induced by intense respiration rates.

\section{CONCLUSIONS}

1. Inflorescences of broccoli show a short shelf life due to intense weight loss and chlorophyll degradation throughout storage at room temperature.

2. Inflorescences have high respiratory rate and show increase on peroxidase activity at later stages of senescence.

3. Carbohydrates are intense metabolized throughout shelf life due to high respiratory activity.

\section{AKNOWLEGMENTS}

To CNPq for the fellowships granted to Fernando Luiz Finger and Laurício Endres.

\section{REFERENCES}

AMARANTE, C.V.T.; PUSCHMANN, R. Relação entre horário de colheita e senescência em folhas de couve. Revista Brasileira de Fisiologia Vegetal, v.5, p.25-29, 1993. 
ARNON, D.I. Copper enzyme in isolated chloroplasts. Polyphenoloxidase in Beta vulgaris. Plant Physiology, v.24, p.411-416, 1949.

CLARKE, S.F.; JAMESON, P.E.; DOWNS, C. The influence of 6-benzylaminopurine on post-harvest senescence of floral tissues of broccoli (Brassica oleracea var. italica). Plant Growth Regulation, v.14, p.21-27, 1994.

CORCUFF, R.; ARUL, J.; HAMZA, F.; CASTAIGNE, F.; MAKHLOUF, J. Storage of broccoli florets in ethanol vapor enriched atmospheres. Postharvest Biology and Technology, v.7, p.219-229, 1996.

DOWNS, C.G.; SOMERFIELD, S.D.; DAVEY, M.C. Cytokinin treatment delays senescence but not sucrose loss in harvested broccoli. Postharvest Biology and Technology, v.11, p.93-100, 1997.

ELSTNER, E.F. Oxygen activation and oxygen toxicity. Annual Review of Plant Physiology, v.33, p.73-96, 1982.

FINGER, F.L.; VIEIRA, G. Controle da perda pós-colheita de água em produtos hortícolas. Viçosa: UFV, 1997. 29p. (Cadernos didáticos, 19).

GILLIES, S.L.; TOIVONEN, P.M.A. Cooling method influences the postharvest quality of broccoli. HortScience, v.30, p.313-315, 1995.

HODGE, J.E.; HOFREITER, B.T. Determination of reducing sugars and carbohydrates. In: WILSTER, R.L.; WOLFROM, M.L. (Eds.). Methods in carbohydrate chemistry. New York: Academic, 1962. v.1, p.380-394.

IRVING, D.E.; BAIRD, V.M. Heat production and respiration by broccoli florets during senescence at $20^{\circ} \mathrm{C}$. New Zealand Journal of Crop and Horticultural Science, v.24, p.199-202, 1996.

KADER, A.A. Respiration and gas exchange of vegetables. In: WEICHMANN, J. (Ed.). Postharvest physiology of vegetables. New York: Marcel Dekker, 1987. p.25-43.

KING, G.A.; MORRIS, S.C. Early compositional changes during postharvest senescence of broccoli. Journal of the American Society for Horticultural Science, v.119, p.1000-1005, 1994.
LAGRIMINI, L.M.; ROTHSTEIN, S. Tissue specificity of tobacco peroxidase isozymes and their induction by wounding and tobacco mosaic virus infection. Plant Physiology, v.84, p.438-442, 1987.

LIPTON, W.J. Senescence of leafy vegetables. HortScience, v.22, p.854-859, 1987.

McCREADY, R.M.J.; GUGGOOLZ, J.; SILVEIRA, V.; OWENS, H.H. Determination of starch and amylose in vegetables. Analytical Chemistry, v.22, p.1156-1158, 1950.

SIMON, T.J.; ROSS, A.F. Enhanced peroxidase activity associated with induction of resistance to tobacco mosaic virus in hypersensitive tobacco. Phytopatology, v.60, 383-384, 1970.

THOMAS, H.; STODDART, J.L. Leaf senescence. Annual Review of Plant Physiology, v.31, p.83-111, 1980.

TIAN, M.S.; DAVIES, L.; DOWNS, C.G.; LIU, X.F.; LILL, R.E. Effects of florets maturity, cytokinin and ethylene on broccoli yellowing after harvest. Postharvest Biology and Technology, v.6, p.29-40, 1995.

TIAN, M.S.; ISLAM, T.; STEVENSON, D.G.; IRVING, D.E. Color, ethylene production, respiration, and compositional changes in broccoli dipped in hot water. Journal of the American Society for Horticultural Science, v.122, p.112-116, 1997.

TOIVONEN, P.M.A. The effects of storage temperature, storage duration, hydro-cooling and micro-perforated wrap on shelf life of broccoli (Brassica oleracea L., Italica Group). Postharvest Biology and Technology, v.10, p.59-65, 1997.

WANG, C.Y. Effect of aminoethoxy analog of rhizobitoxine and sodium benzoate on senescence of broccoli. HortScience, v.12, p.54-56, 1977.

YAMAUCHI, N.; XIA, X.; HASHINAGA, F. Involvement of flavonoid oxidation with chlorophyll degradation by peroxidase in wase satsuma mandarin fruits. Journal of the Japanese Society for Horticultural Science, v.66, p.283-288, 1997. 